\title{
Synthesis and Hypoglycemic Activity of the Derivatives of 4-(1,3-Thiazolidine-5-Ylidene)Pyrazole-3-Carbonic Acid and its Esters
}

\author{
Mykhaylo Bratenko ${ }^{1} \mathbb{D}$, Olesya Perepelytsya ${ }^{1 \mathbb{D}}$, Iryna Yaremii ${ }^{1} \mathbb{D}$, Kateryna Kupchanko ${ }^{1 \mathbb{D}}$, Nadiia \\ Panasenko 1,* (D), Mykhailo Vovk 2 (iD) \\ 1 Department of Medical and Pharmaceutical Chemistry, Bukovinian State MedicalUniversity, 58000 Chernivtsi, Ukraine \\ 2 Department of Mechanism of Organic Reactions, Institute of Organic Chemistry of National Academy of Sciences of \\ Ukraine, 02660 Kyiv, Ukraine \\ * Correspondence: panasenko.n@bsmu.edu.ua (N.P.);
}

Scopus Author ID5780426900

Received: 3.02.2021; Revised: 1.03.2021; Accepted: 3.03.2021; Published: 10.03.2021

\begin{abstract}
A preparatively convenient method for synthesizing a series of new (pyrazole-4yl)methylenethiazolidine structures fictionalized by the carboxylate or carboxylic group in the $3^{\text {rd }}$ position of the pyrazole cycle and by the oxo- thio- or imine groups in the $3^{\text {rd }}$ and $5^{\text {th }}$ positions of the thiazolidine ring is discussed. The method is based on the condensation of 4-formylpyrazole-3-carbonic acids and their ethyl esters with a series of substituted thiazolidines: 1,3-thiazolidine-2,4-dione, 4thioxo-1,3-thiazolidine-2-one, 2-thioxo-1,3-thiazolidine-4-one, and 2-imino-1,3-thiazolidine-4-one. As seen from the biochemical investigations results, a clear hypoglycemic activity has been registered for the compounds mentioned in this work. Five of ten products have ensured a prolonged effect embracing the entire duration of the experiment. 1-Methyl-4[(4-oxo-2-thioxo-1,3-thiazolidine-5-iliden)methyl]$1 \mathrm{H}$-pyrazole-3-carbonic acid caused the deepest decrease in the glucose content (by $2.0 \mathrm{mmole} / \mathrm{L}$ or $30.4 \%$ ), while in the case of the reference medicine pioglitazone, it was only by $1.35 \mathrm{mmole} / \mathrm{L}$ ( 23.9 $\%)$. Some dependence between the compound structure and its pharmaceutical activity was also found. The most prolonged and steady hypoglycemic activity was registered for (pyrazole-4il)methylethiazolidines with methyl group as a substitute in the $1^{\text {st }}$ position and carboxylic group - in the $3^{\text {rd }}$ position. The additional introduction of the methyl and carboxylate groups into the pyrazole scaffold results in a prolonged and more in-depth hypoglycemic effect leading to the 1.4 times lesser drop in glucose concentration as compared to that after administration of the reference medicine.
\end{abstract}

Keywords: 4-formilpyrazole-3-carbonic acids and their esters; substituted 1,3-thiazolidines; (pyrazole4-il)methylenethiazolidine; condensation; hypoglycemic activity; dependence structure-pharmaceutical efficiency.

(C) 2021 by the authors. This article is an open-access article distributed under the terms and conditions of the Creative Commons Attribution (CC BY) license (https://creativecommons.org/licenses/by/4.0/).

\section{Introduction}

The $2^{\text {nd }}$ type of diabetes mellitus is a widely distributed and quite impairing disease, which requires constant efforts applied at the state level to minimize and prevent severe complications of this medical problem. It is recommended to start the glucose-reducing therapy at the early stages of diabetes to improve the patients' life quality [1]. That is why safety issues are extremely important for anti-diabetic medicines, sometimes prescribed for a lifelong period [2]. Besides, many commonly used anti-diabetic medications, except for insulin, reduce the glycosylated hemoglobin content $\left(\mathrm{HbA}_{1 \mathrm{C}}\right)$ by not more than $1 \%$, which is insufficient for 
patients who have long-term diabetes [3-7]. That is why the problem of research and development of new efficient and safe hypoglycemic medicines, including those derived from various heterocyclic compounds, remains very topical.

It is known that the thiazolidinedione series compounds, commonly referred to as 'glitazones' are efficient as peroral sugar-reducing medications. Their therapeutic activity is based on increasing the peripheral tissues' sensitivity to insulin and improvement of glucose utilization. On the other hand, glitazones may cause an abnormal increase of sensitivity of hepatocytes and peripheral tissues to insulin, an increase of the insulin-depending consumption of glucose, decrease in the excretion of glucose from the liver, and decrease in the content of glucose, insulin, and the glycosylated hemoglobin in the blood. Besides, glitazone therapy can lower the content of $\mathrm{HbA}_{1 \mathrm{C}}$ not more than by $0.5-1.4 \%$ only [8].

One of the options for addressing this problem is developing combined medicines that exhibit long-lasting antihyperglycemic effects and can influence pathological symptoms and the causes for their occurrence. Our efforts aimed to synthesize the potential hypoglycemic agents involving the oxo(thio, imino)thiazolidine and the functionalized pyrazole cycles based on the above reasons.

As seen from the scientific works analysis, there is considerable pharmaceutical potential in the series of hybrid compounds consisting of the (1,3-thiazolidine)-5-ylidene fragment bonded in the $4^{\text {th }}$ position with 3 -aryl-substituted pyrazole cycle. Some of these compounds exhibit significant antimicrobial [9-19], anti-inflammatory [20-23], and antidiabetic [24-29] activity, while some others [30-31] act as pancreatic lipase inhibitors.

\section{Materials and Methods}

\subsection{Materials.}

All reactants were of the 'reagent' purity grade and were obtained from a local representative of Sigma-Aldrich and used in the experiments without additional purification. All solvents used in this work were purified by the standard procedures [32]. Experimental methods $[33,34]$ were applied to synthesize the source 1-methyl(phenyl)-4-formylpyrazole-3carbonic acids and their ethyl esters.

\subsection{Chemistry.}

IR spectra of the compounds were recorded in the $\mathrm{KBr}$ pellets by the device Bruker Vertes 70. The NMR ${ }^{1} \mathrm{H}$ spectra were recorded using the spectrometer Varian VXR-400 (at 399.97 MHz) in the DMSO- $d_{6}$ solutions using TMS as an internal standard. Chromatomass spectra were obtained using the device Agilent LC\MSD SL equipped with the column Zorbax SB-C18, 4.6x15 mm, $1.8 \mu \mathrm{m}$ (PN 82(c)75-932) and DMSO as the solvent. The electrospraying technique ionized the samples under atmospheric pressure. Elemental analysis was performed in the analytical laboratory of the Institute of Organic Chemistry of NAS of Ukraine using the Perkin Elmer CHN Analyzer series 2400. Melting points were determined using a Kofler Heizbank apparatus and left uncorrected.

The general procedure of the synthesis of ethyl-4-[(2,4-dioxo-1,3-thiazolidine-5ylidene)methyl]-1H-pyrazole-3-carboxylates (2 a, b) and ethyl-4-[(2-oxo-4-thioxo-1,3thiazolidine-5-ylidene)methyl]- $1 H$-pyrazole-3-carboxylates ( $3 \mathrm{a}, \mathrm{b}$ ) was as follows:3 drops of acetic acid and 1 drop of piperidine were added to the solution of 0.01 mole of the aldehydoester la,b and 0.01 mole of 1,3-thiazolidine-2,4-dione or 4-thioxo-1,3-thiazolidine-2-ones in $15 \mathrm{ml}$ 
of anhydrous benzene and boiled for $2 \mathrm{~h}$. Then the mixture was cooled, the solvent was removed by distillation, and the dry residue was treated with $10 \mathrm{ml}$ of ethanol. Finally, the precipitate was filtered out, washed with distilled water, and then recrystallized from acetic acid.

Ethyl-4-[(2,4-dioxo-1,3-thiazolidine-5-ylidene)methyl]-1 $\boldsymbol{H}$-pyrazole-3-carboxylate (2 a). Yield $92 \%$; m. p.: $168-170^{\circ} \mathrm{C}$. IR $\left(\mathrm{v} / \mathrm{cm}^{-1}\right): 1741,1732(\mathrm{C}=\mathrm{O}), 3339(\mathrm{NH}) .{ }^{1} \mathrm{H}$ NMR: $\delta$ $=1.32\left(\mathrm{t}, 3 \mathrm{H}, \mathrm{CH}_{3}, J=7.2 \mathrm{~Hz}\right), 3.99\left(\mathrm{~s}, 3 \mathrm{H}, \mathrm{CH}_{3}\right), 4.31\left(\mathrm{q}, 2 \mathrm{H}, \mathrm{CH}_{2} \mathrm{O}, J=7.2 \mathrm{~Hz}\right), 8.17(\mathrm{~s}, 1 \mathrm{H}$, $\mathrm{HC}=$ ), 8.18 (s, 1H, H5 pyrazole), 12.38 (br.s, 1H, NH).LC-MS: m/z = 282 [M+1] (100\%). Anal. Calcd. for $\mathrm{C}_{11} \mathrm{H}_{11} \mathrm{~N}_{3} \mathrm{O}_{4} \mathrm{~S}, \%$ : C46.97; H3.94; N 14.94. Found, \% : C 46.68; H 3.86; N 15.16.

Ethyl-4-[(2,4-dioxo-1,3-thiazolidine-5-ylidene)phenyl]-1 $\boldsymbol{H}$-pyrazole-3-carboxylate (2 b). Yield $89 \%$; m. p.: 144-146 ${ }^{\circ} \mathrm{C}$. IR $\left(v / \mathrm{cm}^{-1}\right): 1739,1733(\mathrm{C}=\mathrm{O}), 3344(\mathrm{NH}) .{ }^{1} \mathrm{H}$ NMR: $\delta$ $=1.35\left(\mathrm{t}, 3 \mathrm{H}, \mathrm{CH}_{3}, J=7.2 \mathrm{~Hz}\right), 4.33\left(\mathrm{q}, 2 \mathrm{H}, \mathrm{CH}_{2} \mathrm{O}, J=7.2 \mathrm{~Hz}\right), 7.38\left(\mathrm{t}, 1 \mathrm{H}_{\text {arom }}, J=7.4 \mathrm{~Hz}\right)$, $7.53\left(\mathrm{t}, 2 \mathrm{H}_{\text {arom }} J=7.4 \mathrm{~Hz}\right), 7.84\left(\mathrm{~d}, 2 \mathrm{H}_{\text {arom }} J=7.4 \mathrm{~Hz}\right), 8.12(\mathrm{~s}, 1 \mathrm{H}, \mathrm{HC}=), 8.23(\mathrm{~s}, 1 \mathrm{H}, \mathrm{H} 5$ pyrazole), 12.43 (br.s, 1H, NH). LC-MS: $\mathrm{m} / \mathrm{z}=344[\mathrm{M}+1]$ (100\%). Anal. Calcd. for $\mathrm{C}_{16} \mathrm{H}_{13} \mathrm{~N}_{3} \mathrm{O}_{4} \mathrm{~S}, \%$ : C55.97; H3.82; N 12.24. Found, \% : C 55.71; H3.90; N 12.41.

Ethyl-4-[(2-oxo-4-thioxo-1,3-thiazolidine-5-ylidene)methyl]-1H-pyrazole-3carboxylate (3 a). Yield $83 \%$; m. p.: 231-233 ${ }^{\circ} \mathrm{C}$. IR ( $\left./ \mathrm{cm}^{-1}\right): 1742,1733(\mathrm{C}=\mathrm{O}), 3311(\mathrm{NH})$. ${ }^{1} \mathrm{H}$ NMR: $\delta=1.34\left(\mathrm{t}, 3 \mathrm{H}, \mathrm{CH}_{3}, J=7.2 \mathrm{~Hz}\right), 3.87\left(\mathrm{~s}, 3 \mathrm{H}, \mathrm{CH}_{3}\right), 4.35\left(\mathrm{q}, 2 \mathrm{H}, \mathrm{CH}_{2} \mathrm{O}, J=7.2 \mathrm{~Hz}\right)$, 8.58 (s, 1H, HC=), 8.65 (s, 1H, H5 pyrazole), 13.77 (br.s, 1H, NH). LC-MS: m/z = 298 [M+1] (100\%). Anal. Calcd. for $\mathrm{C}_{11} \mathrm{H}_{11} \mathrm{~N}_{3} \mathrm{O}_{3} \mathrm{~S}_{2}, \%$ : C44.43; H3.73; N 14.13. Found, \% : C44.71; H3.67; N 14.31.

Ethyl-4-[(2-oxo-4-thioxo-1,3-thiazolidine-5-ylidene)phenyl]-1H-pyrazole-3carboxylate (3 b). Yield $78 \%$; m. p.: 147-149 ${ }^{\circ} \mathrm{C}$. IR $\left(v / \mathrm{cm}^{-1}\right)$ : 1738, $1730(\mathrm{C}=\mathrm{O}), 3305(\mathrm{NH})$. ${ }^{1} \mathrm{H}$ NMR: $\delta=1.37\left(\mathrm{t}, 3 \mathrm{H}, \mathrm{CH}_{3}, J=7.2 \mathrm{~Hz}\right), 4.38\left(\mathrm{q}, 2 \mathrm{H}, \mathrm{CH}_{2} \mathrm{O}, J=7.2 \mathrm{~Hz}\right), 7.46\left(\mathrm{t}, 1 \mathrm{H}_{\text {arom }}, J\right.$ $=7.4 \mathrm{~Hz}), 7.56(\mathrm{t}, 2 \mathrm{Harom}, J=7.4 \mathrm{~Hz}), 7.97(\mathrm{~d}, 2 \mathrm{Harom}, J=7.4 \mathrm{~Hz}), 8.56(\mathrm{~s}, 1 \mathrm{H}, \mathrm{HC}=), 8.65(\mathrm{~s}$, 1H, H5 pyrazole), 13.64 (br.s, 1H, NH). LC-MS: m/z = $360[\mathrm{M}+1](100 \%)$. Anal. Calcd. for $\mathrm{C}_{16} \mathrm{H}_{13} \mathrm{~N}_{3} \mathrm{O}_{3} \mathrm{~S}_{2}, \%$ : C53.47; H3.65; N 11.69. Found, \% : C53.27; H3.74; N 11.47.

The general procedure of the synthesis of 4-[(2-oxo-4-thioxo-1,3-thiazolidine-5ylidene)methyl]-1 $H$-pyrazole-3-carboxylic acids (3 c, d), 4-[(4-oxo-2-thioxo-1,3-thiazolidine5-ylidene)methyl]-1H-pyrazole-3-carboxylic acids (4 a, b) and 4-[(2-imino-4-thioxo-1,3thiazolidine-5-yliden)methyl]-1H-pyrazole-3-carboxylicacid (5) was as follows:0.01 g of the anhydrous sodium acetate was added to the solution of 0.002 moles of the aldehydoacid $1 \mathrm{c}, \mathrm{d}$ and 0.002 moles of either 4-thioxo-1,3-thiazolidine-2-one or 2-imino-1,3-thiazolidine-4-one in $10 \mathrm{ml}$ of acetic acid and boiled for $1 \mathrm{~h}$. Then the mixture was cooled, the precipitate was filtered out, washed with distilled water, and recrystallized from acetic acid.

4-[(2-Oxo-4-thioxo-1,3-thiazolidine-5-ylidene)methyl]-1 $\boldsymbol{H}$-pyrazole-3-carboxylic acid $\left(3\right.$ c). Yield $92 \%$; m. p.: 172-174 ${ }^{\circ} \mathrm{C}$. IR $\left(v / \mathrm{cm}^{-1}\right): 1736(\mathrm{C}=\mathrm{O}), 3321(\mathrm{NH}), 2550-2751$ $(\mathrm{COOH}) .{ }^{1} \mathrm{HNMR}: \delta=3.99\left(\mathrm{~s}, 3 \mathrm{H}, \mathrm{CH}_{3}\right), 8.27(\mathrm{~s}, 1 \mathrm{H}, \mathrm{HC}=), 8.63$ (s, 1H, H5 pyrazole), 13.73 (br.s, $1 \mathrm{H}, \mathrm{NH})$. (COOH protons are exchanged with water molecules of deuterosolvent). LCMS: $\mathrm{m} / \mathrm{z}=270[\mathrm{M}+1](100 \%)$. Anal. Calcd. for $\mathrm{C}_{9} \mathrm{H}_{7} \mathrm{~N}_{3} \mathrm{O}_{3} \mathrm{~S}_{2}, \%: \mathrm{C} 40.14 ; \mathrm{H} 2.62 ; \mathrm{N}$ 15.60. Found, \% : C40.39; H2.71; N 15.77.

\section{4-[(2-Oxo-4-thioxo-1,3-thiazolidine-5-ylidene)phenyl]-1H-pyrazole-3-carboxylic}

acid (3 d). Yield $79 \%$; m. p. $263-265^{\circ} \mathrm{C}$. IR $\left(v / \mathrm{cm}^{-1}\right)$ : 1740, $(\mathrm{C}=\mathrm{O}), 3317(\mathrm{NH}), 2546-2745$ $(\mathrm{COOH}) .{ }^{1} \mathrm{H}$ NMR: $\delta=7.46\left(\mathrm{t}, 1 \mathrm{H}_{\text {arom }} J=7.2 \mathrm{~Hz}\right), 7.57$ (t, $\left.2 \mathrm{H}_{\text {arom }}, J=7.2 \mathrm{~Hz}\right), 7.97$ (d, $2 \mathrm{H}_{\text {arom, }}$ $J=7.2 \mathrm{~Hz}$ ), 8.65 (s, 1H, HC=), 8.70 (s, 1H, H5 pyrazole), 13.73 (br.s, 1H, NH). (COOH protons are exchanged with water molecules of deuterosolvent). LC-MS: $\mathrm{m} / \mathrm{z}=332[\mathrm{M}+1](100 \%)$. 
Anal. Calcd. for $\mathrm{C}_{14} \mathrm{H}_{9} \mathrm{~N}_{3} \mathrm{O}_{3} \mathrm{~S}_{2}, \%$ : C50.75; H2.74; N 12.68. Found, \% : C50.48; H2.82; N 12.47.

4-[(4-Oxo-2-thioxo-1,3-thiazolidine-5-ylidene)methyl]-1H-pyrazole-3-carboxylic acid (4 a). Yield $96 \%$; m. p.: 172-174 ${ }^{\circ} \mathrm{C}$. IR $\left(\mathrm{v} / \mathrm{cm}^{-1}\right)$ : 1737, $1725(\mathrm{C}=\mathrm{O}), 3301(\mathrm{NH}), 2569-$ $2744(\mathrm{COOH}) .{ }^{1} \mathrm{HNMR}: \delta=3.98\left(\mathrm{~s}, 3 \mathrm{H}, \mathrm{CH}_{3}\right), 8.03$ (s, 1H, HC=), 8.21 (s, 1H, H5 pyrazole), 13.28 (br.s, 1H, NH). (COOH protons are exchanged with water molecules of deuterosolvent). LC-MS: $\mathrm{m} / \mathrm{z}=270[\mathrm{M}+1](100 \%)$. Anal. Calcd. for $\mathrm{C}_{9} \mathrm{H}_{7} \mathrm{~N}_{3} \mathrm{O}_{3} \mathrm{~S}_{2}, \%$ : C40.14; H2.62; N 15.60. Found, \% : C39.88; H2.71; N 15.81.

\section{4-[(4-Oxo-2-thioxo-1,3-thiazolidine-5-ylidene)phenyl]-1H-pyrazole-3-carboxylic}

acid (4 b). Yield $87 \%$; m. p.: 276-278 ${ }^{\circ}$. IR $\left(v / \mathrm{cm}^{-1}\right): 1735,1726(\mathrm{C}=\mathrm{O}), 3295(\mathrm{NH}), 2574-$ $2760(\mathrm{COOH}) .{ }^{1} \mathrm{H}$ NMR: $\delta=7.45\left(\mathrm{t}, 1 \mathrm{H}_{\text {arom }} J=7.2 \mathrm{~Hz}\right), 7.55\left(\mathrm{t}, 2 \mathrm{H}_{\text {arom }}, J=7.2 \mathrm{~Hz}\right), 7.99$ (d, $\left.2 \mathrm{H}_{\text {arom }}, J=7.2 \mathrm{~Hz}\right), 8.06(\mathrm{~s}, 1 \mathrm{H}, \mathrm{HC}=), 8.61(\mathrm{~s}, 1 \mathrm{H}, \mathrm{H} 5$ pyrazole), NH. (COOH protons are exchanged with water molecules of deuterosolvent). LC-MS: $\mathrm{m} / \mathrm{z}=332[\mathrm{M}+1]$ (100\%). Anal. Calcd. for $\mathrm{C}_{14} \mathrm{H}_{9} \mathrm{~N}_{3} \mathrm{O}_{3} \mathrm{~S}_{2}, \%$ : C50.75; H2.74; $\mathrm{N}$ 12.68. Found, \% : C51.02; H2.83; N 12.47.

4-[(2-Imino-4-oxo-1,3-thiazolidine-5-ylidene)phenyl]-1H-pyrazole-3-carboxylic acid (5). Yield $76 \%$; m. p.: 181-183 ${ }^{\circ} \mathrm{C}$. IR $\left(v / \mathrm{cm}^{-1}\right): 1730,1722(\mathrm{C}=\mathrm{O}), 3358,3286(\mathrm{NH})$, 2485-2698 (COOH). ${ }^{1} \mathrm{H}$ NMR: $\delta=7.45\left(\mathrm{t}, 1 \mathrm{H}_{\text {arom }}, J=7.4 \mathrm{~Hz}\right), 7.58\left(\mathrm{t}, 2 \mathrm{H}_{\text {arom }}, J=7.4 \mathrm{~Hz}\right)$, 7.94 (d, 2Harom, $J=7.4 \mathrm{~Hz}), 8.05$ (s, $1 \mathrm{H}, \mathrm{HC}=), 8.56$ (s, 1H, H5 pyrazole), 8.74 (s, 1H, NH), 8.97 (br.s, 1H, COOH), 9.15 (s, 1H, NH).LC-MS: m/z = 315 [M+1] (100\%). Anal. Calcd. for $\mathrm{C}_{14} \mathrm{H}_{10} \mathrm{~N}_{4} \mathrm{O}_{3} \mathrm{~S}, \%$ : C53.50; H3.21; N 17.82. Found, \% : C53.79; H3.14; N18.01.

\subsection{Hypoglycemic activity.}

A group of 112 white adult nonlinear male rats weighing 200-250 g was used to investigate the hypoglycemic activity of the compounds synthesized in this work. All rats were kept in standard vivarium conditions before the experiments, and all manipulations with them were carried out in strict accordance with general principles of humane treatment of animals and in the frameworks of Ethical principles for conducting the experiments involving animals approved at the First National Congress of Bioethics (Kyiv, 2000). European Convention for the Protection of Vertebrate Animals used for Experimental and Other Scientific Purposes (Strasbourg, 1986) was also thoroughly observed.

The groups of 8 animals were formed by a random selection of the rats in such a way that the bodyweight deviation within every group did not exceed $15 \%$. «Glutazone» (by LLC "KUSUM PHARM"), active substance - polyglitazone hydrochloride recalculated to polyglitazone $(\mathrm{M}=356), 15 \mathrm{mg}$, pioglitazone (5-\{4-[2-(5-ethylpyridine-2-yl)etoxy]benzyl $\}$ thiazolidine-2,4-dione, $\mathrm{M}=356$ ) was used as a control reference medication, which has been administered as $0.0214 \mathrm{mmole} / \mathrm{kg}$ according to

\section{Results}

\subsection{Chemistry.}

A series of new (pyrazole-4-yl)methylenthiazolidine structures functionalized with carboxylate or carboxyl group in the $3^{\text {rd }}$ position of the pyrazole cycle and oxo- thio- or iminogroups in the $3^{\text {rd }}$ and $5^{\text {th }}$ positions of the instruction for its use. Intragastric administration was done on an empty stomach in the $3 \%$ starch suspension using the non-traumatic probe. The starch suspension containing no medications was administered to the control group of animals by the same procedure. The hypoglycemic activity was evaluated by the changes in glucose 
concentration in the animal's blood before and 2, 4, 6, 8, and 10 hours after the administration using the express glucometer «OneTouchSelectSimple». Then all the results were statistically processed with the aid of MS Excel and using the non-parametric Mann-Whitney criterion to check the validity of experimental data. Student's t-test $\mathrm{P}<0.05$ was chosen as a proof of the data relevance, and validity thiazolidine cycle was synthesized. Then all these compounds were involved in the screening of hypoglycemic efficiency. The ethyl esters of 4-formylpyrazole-3carboxylic acids $1 \mathrm{a}, \mathrm{b}$ synthesized in [33] and the acids $1 \mathrm{c}, \mathrm{d}$ corresponding to these esters and synthesized in our previous work [34] were used as the substrate for the synthesis of the above-mentioned functionalized compounds. It has been found that the aldehyde esters $1 \mathrm{a}, \mathrm{b}$ react with 1,3-thiazolidine-2,4-dione or 4-thioxo-1,3-thiazolidine-2-one at 3 hours boiling in benzene and with the presence of catalytic additives of acetic acid and piperidine. As a result, the 4-(thiazolidine-5-yliden pyrazoles $2 \mathrm{a}, \mathrm{b}$ and $3 \mathrm{a}, \mathrm{b}$ are formed with a yield 78-92\%. On the other hand, it requires to boil a mixture of the aldehyde acids $1 \mathrm{c}$, d with 4-thioxo-1,3thiazolidine -2-one or with 2-thioxo-1,3-thiazolidine-4-one or with 2-imino-1,3-thiazolidine 4-one for 1 hour in acetic acid with a catalytic admixture of anhydrous sodium acetate to obtain the corresponding yliden-derivatives $3 \mathrm{c}, \mathrm{d}, 4 \mathrm{a}, \mathrm{b}$ and 5 with a yield 76-96 \% (see Scheme 1).

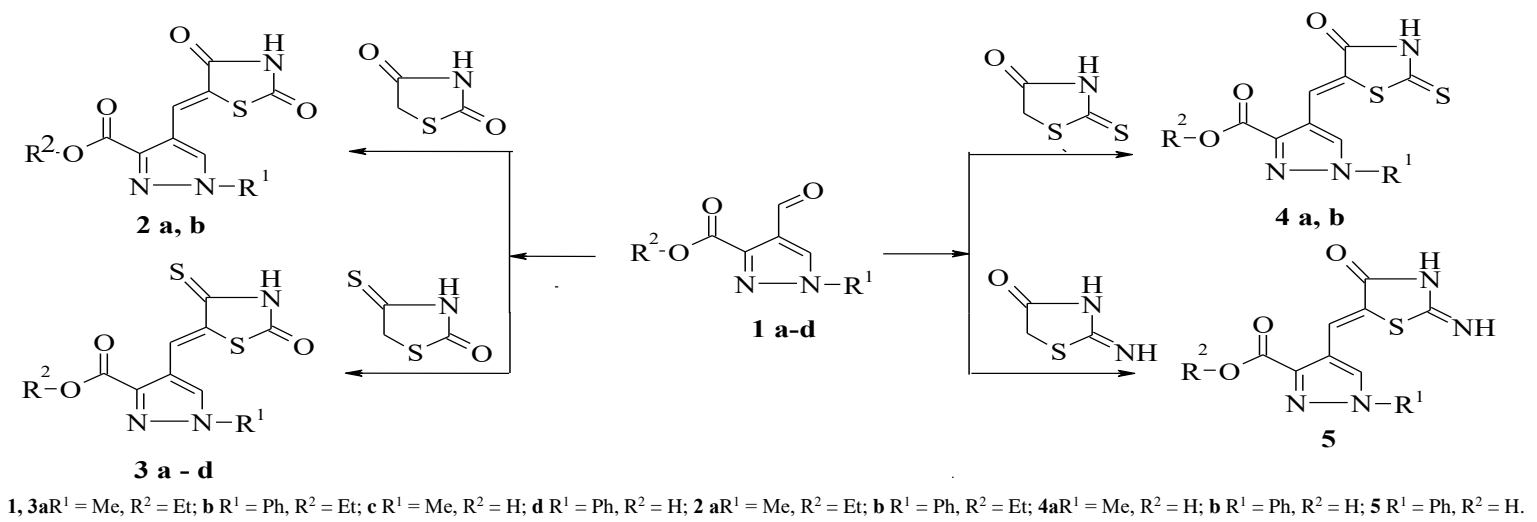

Scheme 1. Synthesis of pyrazole derivatives 2 a, b 3 a-d, 4 a,b and 5 .

The synthesized compounds' structure was confirmed by their IR-, NMR- and ${ }^{1} \mathrm{H}$ spectra and the elemental analysis. It should be emphasized that the NMR and ${ }^{1} \mathrm{H}$ spectra were especially interesting because of the characteristic singlet formed at the condensation of an yliden fragment within the ranges 8.12-8.17 m.p. (mass parts) (compounds $2 \mathrm{a}, \mathrm{b}$ ), 8.27-8.65 m.p. (3 a-d) and 8.03-8.05 m.p. (4 a, b and 5).

\subsection{Investigation in antihyperglycemic activity.}

The results related to the influence of compounds $2 \mathrm{a}, \mathrm{b}, 3 \mathrm{a}-\mathrm{d}, 4 \mathrm{a}, \mathrm{b}, 5$, and the sodium salt $3 \mathrm{c}^{\prime}$ synthesized from the acid $3 \mathrm{c}$ on the blood glucose concentration are given in Table 1. It is seen that the compounds $3 \mathrm{a}-\mathrm{d}, 3 \mathrm{c}$, and $4 \mathrm{a}$, b cause a statistically reliable lowering in the glucose content. The compounds $3 \mathrm{a}, \mathrm{c}, \mathrm{c}^{\prime}, \mathrm{d}$, and $4 \mathrm{~b}$ provide a long-term antihyperglycemic activity that lasted throughout the entire period of this experiment. A single administration of $0.0214 \mathrm{mmole} / \mathrm{kg}$ of pioglitazone causes a decrease in the glucose content by 9.2, 20.7, 23.0, and $23.9 \%$ after $4,6,8$, and 10 hours after the administration, respectively. The most significant decrease in the glucose content by $2.0 \mathrm{mmole} / \mathrm{L}$ (30.4\%) has been determined for the compound $3 \mathrm{c}$, while the control medication decreased this content by $1.35 \mathrm{mmole} / \mathrm{L}$ or $23.9 \%$ only.

Unlike other synthesized derivatives of thiazolidinepyrazoles, compound 5 ensured a long-term hyperglycemic activity throughout the entire experiment. This compound's maximal 
activity was registered 2 hours after administration, and the relative glucose content increased 1.3 times $(\mathrm{P}<0.05)$. Therefore, it is obvious that the synthesized (pyrazole-4yl)methylenthiazolidines exhibit some hypoglycemic effect and can be considered as potential objects to carry out further investigations in this field.

Table 1. Changes in the blood glucose content (mmole/L) in rats after the peroral administration of 0.0214 mmole/kg of the compounds $2 \mathrm{a}, \mathrm{b}, 3 \mathrm{a}-\mathrm{d}, 4 \mathrm{a}, \mathrm{b}, 5$.

\begin{tabular}{|c|c|c|c|c|c|c|}
\hline № & 0 hour & 2 hour & 4 hour & 6 hour & 8 hour & 10 hour \\
\hline Control & $5.86 \pm 0.175$ & $5.55 \pm 0.195$ & $5.23 \pm 0.117$ & $5.2 \pm 0.095$ & $5.4 \pm 0.385$ & $5.3 \pm 0.24$ \\
\hline $\begin{array}{l}\text { Pioglitazo } \\
\text { ne }\end{array}$ & $5.65 \pm 0.118$ & $5.4 \pm 0.85$ & $\begin{array}{c}5.13 \pm 0.151 \\
\mathrm{P}<0.05\end{array}$ & $\begin{array}{c}4.48 \pm 0.113 \\
\mathrm{P}<0.001\end{array}$ & $\begin{array}{c}4.35 \pm 0.359 \\
\mathrm{P}<0.01\end{array}$ & $\begin{array}{c}4.3 \pm 0.46 \\
\mathrm{P}<0.05\end{array}$ \\
\hline $2 a$ & $5.85 \pm 0.919$ & $5.65 \pm 0.819$ & $4.8 \pm 0.424$ & $5.15 \pm 0.213$ & $5.3 \pm 0.141$ & $5.31 \pm 0.441$ \\
\hline $2 b$ & $5.78 \pm 0.828$ & $6.43 \pm 0.891$ & $5.72 \pm 0.728$ & $5.8 \pm 0.681$ & $5.5 \pm 2.84$ & $5.54 \pm 1.181$ \\
\hline $3 a$ & $6.3 \pm 0.571$ & $6.34 \pm 0.128$ & $5.61 \pm 0.699$ & $\begin{array}{c}.35 \pm 0.099 \\
\mathrm{P}<0.05\end{array}$ & $\begin{array}{c}4.51 \pm 0.1085 \\
\mathrm{P}<0.05\end{array}$ & $\begin{array}{c}4.91 \pm 0.103 \\
\mathrm{P}_{1}<0.05\end{array}$ \\
\hline $3 \mathbf{b}$ & $\begin{array}{c}6.97 \pm 0.569 \\
P_{1}<0.05\end{array}$ & $5.91 \pm 0.869$ & $\begin{array}{c}5.1 \pm 0.608 \\
\mathrm{P}<0.05\end{array}$ & $\begin{array}{c}6.1 \pm 0.705 \\
P_{1}<0.05\end{array}$ & $6.17 \pm 0.611$ & $6.47 \pm 0.811$ \\
\hline $3 c$ & $\begin{array}{c}6.65 \pm 0.112 \\
\mathrm{P}_{1}<0.001 \\
\mathrm{P}_{2}<0.05\end{array}$ & $6.31 \pm 0.103$ & $\begin{array}{c}5.58 \pm 0.144 \\
\mathrm{P}_{1}<0.05\end{array}$ & $\begin{array}{c}5.43 \pm 0.134 \\
\mathrm{P}_{1}<0.001\end{array}$ & $5.45 \pm 0.124$ & $4.63 \pm 0.225$ \\
\hline $3 c^{\prime}$ & $5.43 \pm 0.68$ & $4.73 \pm 0.818$ & $4.3 \pm 0.86$ & $\begin{array}{c}3.83 \pm 0.106 \\
\mathrm{P}<0.05 \\
\mathrm{P}_{1}<0.001 \\
\mathrm{P}_{2}<0.001 \\
\end{array}$ & $4.08 \pm 0.655$ & $\begin{array}{c}4.3 \pm 0.105 \\
\mathrm{P}_{2}<0.05\end{array}$ \\
\hline 3d & $\begin{array}{c}6.17 \pm 0.115 \\
\mathrm{P}_{1}<0.01\end{array}$ & $6.1 \pm 0.315$ & $5.97 \pm 0.924$ & $\begin{array}{c}4.4 \pm 0.1 \\
\mathrm{P}<0.001 \\
\mathrm{P}_{2}<0.001\end{array}$ & $\begin{array}{c}4.23 \pm 0.109 \\
\mathrm{P}<0.001 \\
\mathrm{P}_{2}<0.05\end{array}$ & $\begin{array}{c}4.73 \pm 0.664 \\
\mathrm{P}=0.05\end{array}$ \\
\hline $4 a$ & $5.47 \pm 0.321$ & $5 \pm 0.625$ & $4.7 \pm 0.436$ & $\begin{array}{c}5.0 \pm 0.104 \\
\mathrm{P}_{1}<0.01\end{array}$ & $4.73 \pm 0.651$ & $4.9 \pm 0.954$ \\
\hline $4 b$ & $5.83 \pm 0.252$ & $5.53 \pm 0.153$ & $5.0 \pm 0.557$ & $4.9 \pm 0.556$ & $\begin{array}{c}4.47 \pm 0.109 \\
\mathrm{P}<0.001\end{array}$ & $\begin{array}{c}4.87 \pm 0.108 \\
\mathrm{P}<0.01\end{array}$ \\
\hline 5 & $5.67 \pm 0.058$ & $\begin{array}{c}7.5 \pm 0.844 \\
\mathrm{P}<0.05 \\
\mathrm{P}_{2}<0.05\end{array}$ & $\begin{array}{c}6.83 \pm 0.673 \\
\mathrm{P}_{1}<0.05 \\
\mathrm{P}_{2}<0.05\end{array}$ & $\begin{array}{c}6.57 \pm 0.896 \\
\mathrm{P}_{1}<0.05\end{array}$ & $\begin{array}{c}6.61 \pm 0.661 \\
P_{1}<0.05\end{array}$ & $\begin{array}{c}6.60 \pm 0.56 \\
\mathrm{P}_{1}<0.05 \\
\mathrm{P}_{2}=0.05\end{array}$ \\
\hline
\end{tabular}

Note $\mathrm{P}$ - relative the baseline; $\mathrm{P}_{1}$ - relative the control medication; $\mathrm{P}_{2}$ - relative the control group of animals.

It seems reasonable to investigate the dependence of the selected substances' hypoglycemic activity on their structural composition. It was found that different substitutes in the $1^{\text {st }}$ and $2^{\text {nd }}$ positions of the pyrazole cycle and the $3^{\text {rd }}$ and $5^{\text {th }}$ positions of the thiazolidine cycle can affect the compounds' hypoglycemic activity. For instance, compound 3 provides long-term hypoglycemic activity and ensures the lowest glucose concentration 6 hours after its administration. The concentration changes are smooth, and the relative decrease in the concentration was 1.45 times $(\mathrm{P}<0.05)$. If the methyl substituent in the $1^{\text {st }}$ position of the pyrazole cycle was substituted with a phenyl group (compound $3 \mathrm{~b}$ ), the lowest glucose concentration was reached faster, after 4 hours, and the relative decrease was 1.4 times $(\mathrm{P}<0.05)$. On the contrary, the lowest glucose concentration was reached 10 hours after the administration if the ester group in 3 a was substituted with a carboxylate group in the $3^{\text {rd }}$ position of the pyrazole ring (compound $3 \mathrm{c}$ ). The relative decrease in glucose concentration for $3 \mathrm{c}$ was 1.4 times $(\mathrm{P}<0.001)$. It should be emphasized that the glucose content decreased 1.2 times $(\mathrm{P}<0.05)$ even after 4 hours and remained below this point until the $8^{\text {th }}$ hour after the administration. This efficiency is similar to that of the control medication pioglitazone, which ensures a 1.1-1.3 times decrease in the blood glucose concentration. Changes in concentration also remain smooth, and it does not jump by more than $2.02 \mathrm{mmole} / \mathrm{L}$. Thus, it is seen that the 
hypoglycemic efficiency can be prolonged by introducing the methyl and carboxyl groups into the pyrazole scaffold. In both cases, the glucose blood content decreases by 1.4 times, which is close to that of pioglitazone.

Transformation of the carboxylate group in $3 \mathrm{c}$ into the sodium-carboxylate (performed in situ by adding an equimolar amount of sodium hydroxide - see compound $3 \mathrm{c}^{\prime}$ ) shifts the point of minimum glucose concentration from 10 to 6 hours after administration leaving its depth unchanged. On the other hand, if the methyl group of $3 \mathrm{c}$ is substituted with phenyl (compound $3 \mathrm{~d}$ ), the minimum shifts from 10 to 8 hours. This effect persisted throughout the entire experimental series, and the relative glucose concentration decrease was 1.46 times $(\mathrm{P}<0.001)$ at the $8^{\text {th }}$ hour after administration. The concentration was changing smoothly, without sharp jumps with the maximal change by $1.94 \mathrm{mmole} / \mathrm{L}$. No statistically relevant influence of changes in the substituent's positions in thiazolidine ring (compound $4 \mathrm{~b}$ ) on the hypoglycemic activity was found. Thus, the substitution of the carboxyl group in the $3^{\text {rd }}$ position of the pyrazole cycle with a carboxylate group and the methyl group with a phenyl group results in some decrease in the duration hypoglycemic effect of the abovementioned compounds.

Suppose the carboxyl group (compound $3 \mathrm{~d}$ ) is substituted with an ester ( $3 \mathrm{~b}$ ). In that case, the maximal decrease in the glucose concentration shifts from the $8^{\text {th }}$ to $4^{\text {th }}$ hour after the administration while its depth remains unchanged. Therefore, this substitution results in a prolonged hypoglycemic effect.

Compound $4 \mathrm{~d}$ exhibited a 10-hour long hypoglycemic effect with 1.3 times relative decrease in the glucose concentration $(\mathrm{P}<0.001)$ reached after 8 hours. Noexpectedeffectwas registered after substitution the phenyl group with a methyl (see compound 4a) though the glucose content increased by 1.3 times $(\mathrm{P}<0.05)$ at the $2^{\text {nd }}$ hour after substitution the thio-group in the $5^{\text {th }}$ position of the thiazolidine ring with its imino-analog (see compound 5). The latter effect lasted throughout the entire length of the experiment. Therefore, it is obvious that the introduction of the imino-group to the $5^{\text {th }}$ position of the thiazolidine cycle leads to an enhancement in the compounds' hypoglycemic activity.

It can be concluded that according to the preliminary screening results, the most prolonged and efficient hypoglycemic activity was found for the compounds with the methyl substituent in the $1^{\text {st }}$ and the carboxyl substituent in the $3^{\text {rd }}$ position of the pyrazole ring. This result can be considered as proof of the primary importance of structural modification of the pyrazole-thiazolidine compounds in the context of their pharmaceutical activity.

\section{Conclusions}

New derivatives of 4-[(1,3-thiazolidine-5-yliden)methyl]pyrazole-3-carboxylic acid and its ethyl esters have been synthesized through the condensation of 4-formylpyrazole-3carboxylicacids, and their ethyl esters with 3,5-(oxo-, thio-, imino-)substituted thiazolidines. The clear hypoglycemic activity was determined by their preliminary pharmaceutical screening, but this issue requires further researches. The highest hypoglycemic activity has been determined for 1-methyl-4[(4-oxo-2-thioxo-1,3-thiazolidine-5-yliden)methyl]-1Hpyrazole-3-carboxylicacid. Since this activity is higher than that of the control medication pioglitazone, the above compound can be considered a promising substrate for developing new anti-diabetic medications. 


\section{Funding}

This research received no external funding.

\section{Conflicts of Interest}

The authors declare no conflict of interest.

\section{References}

1. Pankiv, V. New guidelines of the American Diabetes Association 2018 on the diagnosis and treatment of diabetes mellitus. Mizhnarodnyiendokrynolohichnyizhurnal. 2018, 14, 94-98, https://doi.org/10.22141/22240721.14.1.2018.127099.

2. Kovalevska, I.V.; Ruban, O.A.; Yevtushenko, O.M. Researches of the assortment of drugs for the treatment of diabetes II type on the pharmaceutical market of Ukraine. Farm. Zh. 2019, 13-23, https://doi.org/10.32352/0367-3057.2.19.02.

3. Chaudhury, A.; Duvoor, C.; Reddy Dendi, V.S.; Kraleti, S.; Chada, A.; Ravilla, R.; Marco, A.; Shekhawat, N.S.; Montales, M.T.; Kuriakose, K.; Sasapu, A.; Beebe, A.; Patil, N.; Musham, C.K.; Lohani, G.P.; Mirza, W. Clinical Review of Antidiabetic Drugs: Implications for Type 2 Diabetes Mellitus Management. Front. Endocrinol. (Lausanne) 2017, 8, 6, https://doi.org/10.3389/fendo.2017.00006.

4. Nanjan, M.J.; Mohammed, M.; Prashantha Kumar, B.R.; Chandrasekar, M.J.N. Thiazolidinediones as antidiabetic agents: A critical review. Bioorg. Chem. 2018, 77, 548-567, https://doi.org/10.1016/j.bioorg.2018.02.009.

5. Bhosle, M.R.; Mali, J.R.; Pal, S.; Srivastava, A.K.; Mane, R.A. Synthesis and antihyperglycemic evaluation of new 2-hydrazolyl-4-thiazolidinone-5-carboxylic acids having pyrazolyl pharmacophores. Bioorg. Med. Chem. Lett. 2014, 24, 2651-2654, https://doi.org/10.1016/j.bmcl.2014.04.064.

6. Abdellatif, K.R.A.; Fadaly, W.A.A.; Kamel, G.M.; Elshaier, Y.A.M.M.; El-Magd, M.A. Design, synthesis, modeling studies and biological evaluation of thiazolidine derivatives containing pyrazole core as potential anti-diabetic PPAR- $\gamma$ agonists and anti-inflammatory COX-2 selective inhibitors. Bioorg. Chem. 2019, 82, 86-99, https://doi.org/10.1016/j.bioorg.2018.09.034.

7. Kaur Manjal, S.; Kaur, R.; Bhatia, R.; Kumar, K.; Singh, V.; Shankar, R.; Kaur, R.; Rawal, R.K. Synthetic and medicinal perspective of thiazolidinones: A review. Bioorg. Chem. 2017, 75, 406-423, https://doi.org/10.1016/j.bioorg.2017.10.014.

8. Stumvoll, M.; Häring, H.-U. Glitazones: clinical effects and molecular mechanisms. Ann. Med. 2002, 34, 217-224, https://doi.org/10.1080/ann.34.3.217.224.

9. Mona, A.H.; Yasser, H.Z.; Wafaa, A.M.; Abdou, O.A. Synthesis, Characterization, Antimicrobial Activity and Anticancer of Some New Pyrazolo[1,5-a]pyrimidines and Pyrazolo[5,1-c]1,2,4-triazines. Medicinal Chemistry 2020, 16, 750-760, https://doi.org/10.2174/1573406415666190620144404.

10. Trotsko, N.; Golus, J.; Kazimierczak, P.; Paneth, A.; Przekora, A.; Ginalska, G.; Wujec, M. Design, synthesis and antimycobacterial activity of thiazolidine-2,4-dione-based thiosemicarbazone derivatives. Bioorg Chem. 2020, 97, 103676, https://doi,org/10.1016/j.bioorg.2020.103676.

11. Hammad, S.G.; El-Gazzar, M.G.; Abutaleb, N.S.; Li, D.; Ramming, I.; Shekhar, A.; Abdel-Halim, M.; Elrazaz, E.Z.; Seleem, M.N.; Bilitewski, U.; Abouzid, K.A.M.; El-Hossary, E.M. Synthesis and antimicrobial evaluation of new halogenated 1,3-Thiazolidin-4-ones. Bioorg. Chem. 2020, 95, 103517, https://doi.org/10.1016/j.bioorg.2019.103517.

12. Sahiba, N.; Sethiya, A.; Soni, J.; Agarwal, D.K.; Agarwal, S. Saturated Five-Membered Thiazolidines and Their Derivatives: From Synthesis to Biological Applications. Top. Curr. Chem. 2020, 378, 34, https://doi.org/10.1007/s41061-020-0298-4.

13. Abdelhamid, A.O.; El Sayed, I.E.; Zaki, Y.H.; Hussein, A.M.; Mangoud, M.M.; Hosny, M.A. Utility of 5(furan-2-yl)-3-(p-tolyl)-4,5-dihydro-1H-pyrazole-1-carbothioamide in the synthesis of heterocyclic compounds with antimicrobial activity. BMC Chemistry 2019, 13, 48, https://doi.org/10.1186/s13065-0190566-y.

14. Neri, F.S.M.; Júnior, D.B.C.; Froes, T.Q.; da Silva, P.B.G.; do Egito, M.S.; Moreira, P.O.L.; de Pilla Varotti, F.; Castilho, M.S.; Teixeira-Neto, R.G.; de Albuquerque, J.F.C.; Leite, F.H.A. Antileishmanial activity 
evaluation of thiazolidine-2,4-dione against Leishmania infantum and Leishmania braziliensis. Parasitol. Res. 2020, 119, 2263-2274, https://doi.org/10.1007/s00436-020-06706-3.

15. Navjot Singh, S.; Deo Nandan, P.; Rajesh, K.S. Synthesis, Anticancer, and Antibacterial Studies of Benzylidene Bearing 5-substituted and 3,5-disubstituted-2,4-Thiazolidinedione Derivatives. Medicinal Chemistry 2021, 17, 369-379, https://doi.org/10.2174/1573406416666200512073640.

16. El-Adl, K.; Sakr, H.; Nasser, M.; Alswah, M.; Shoman, F.M.A. 5-(4-Methoxybenzylidene)thiazolidine-2,4dione-derived VEGFR-2 inhibitors: Design, synthesis, molecular docking, and anticancer evaluations. Arch. Pharm. 2020, 353, 2000079, https://doi.org/10.1002/ardp.202000079.

17. Abd Alhameed, R.; Almarhoon, Z.; Bukhari, S.I.; El-Faham, A.; de la Torre, B.G.; Albericio, F. Synthesis and Antimicrobial Activity of a New Series of Thiazolidine-2,4-diones Carboxamide and Amino Acid Derivatives. Molecules 2020, 25, https://doi.org/10.3390/molecules25010105.

18. Takate, S.J.; Shinde, A.D.; Karale, B.K.; Akolkar, H.; Nawale, L.; Sarkar, D.; Mhaske, P.C. Thiazolylpyrazole derivatives as potential antimycobacterial agents. Bioorg. Med. Chem. Lett. 2019, 29, 1199-1202, https://doi.org/10.1016/j.bmcl.2019.03.020.

19. Zeinab, A.M.; Fatimah, A.; Mohie, E.M.Z.; Thoraya, A.F.; Magda, A.A. Synthesis of Novel Bis-pyrazole Derivatives as Antimicrobial Agents. Mini-Rev. Med. Chem. 2019, 19, 1276-1290, https://doi.org/10.2174/1389557519666190313095545.

20. Elkamhawy, A.; Kim, N.y.; Hassan, A.H.E.; Park, J.-e.; Paik, S.; Yang, J.-E.; Oh, K.-S.; Lee, B.H.; Lee, M.Y.; Shin, K.J.; Pae, A.N.; Lee, K.-T.; Roh, E.J. Thiazolidine-2,4-dione-based irreversible allosteric IKK$\beta$ kinase inhibitors: Optimization into in vivo active anti-inflammatory agents. Eur. J. Med. Chem. 2020, 188, 111955, https://doi.org/10.1016/j.ejmech.2019.111955.

21. Sucheta; Tahlan, S.; Verma, P.K. Synthesis, SAR and in vitro therapeutic potentials of thiazolidine-2,4diones. Chem. Cent. J. 2018, 12, 129, https://doi.org/10.1186/s13065-018-0496-0.

22. Zhou, S.; Zhou, Z.; Ding, K.; Yuan, Y.; Loftin, C.; Zheng, F.; Zhan, C.-G. DREAM-in-CDM Approach and Identification of a New Generation of Anti-inflammatory Drugs Targeting mPGES-1. Sci. Rep. 2020, 10, 10187, https://doi.org/10.1038/s41598-020-67283-0.

23. Elkamhawy, A.; youn Kim, N.; Hassan, A.H.E.; Park, J.-e.; Yang, J.-E.; Elsherbeny, M.H.; Paik, S.; Oh, K.S.; Lee, B.H.; Lee, M.Y.; Shin, K.J.; Pae, A.N.; Lee, K.-T.; Roh, E.J. Optimization study towards more potent thiazolidine-2,4-dione IKK- $\beta$ modulator: Synthesis, biological evaluation and in silico docking simulation. Bioorg. Chem. 2019, 92, 103261, https://doi.org/10.1016/j.bioorg.2019.103261.

24. Karumanchi, S.K.; Atmakuri, L.R.; Mandava, V.B.R.; Rajala, S. Synthesis and Hypoglycemic and Antiinflammatory Activity Screening of Novel Substituted 5-[Morpholino (Phenyl) Methyl]-Thiazolidine-2, 4Diones and Their Molecular Docking Studies. Turkish Journal of Pharmaceutical Sciences 2019, 16, 380, https://doi.org/10.4274/tjps.galenos.2018.82612.

25. Bansal, G.; Singh, S.; Monga, V.; Thanikachalam, P.V.; Chawla, P. Synthesis and biological evaluation of thiazolidine-2,4-dione-pyrazole conjugates as anti-diabetic, anti-inflammatory and antioxidant agents. Bioorg. Chem. 2019, 92, 103271, https://doi.org/10.1016/j.bioorg.2019.103271.

26. Lebovitz, H.E. Thiazolidinediones: the Forgotten Diabetes Medications. Curr. Diab. Rep. 2019, 19, 151, https://doi.org/10.1007/s11892-019-1270-y.

27. Barmak, A.; Niknam, K.; Mohebbi, G. Synthesis, Structural Studies, and $\alpha$-Glucosidase Inhibitory, Antidiabetic, and Antioxidant Activities of 2,3-Dihydroquinazolin-4(1H)-ones Derived from Pyrazol-4carbaldehyde and Anilines. ACS Omega 2019, 4, 18087-18099, https://doi.org/10.1021/acsomega.9b01906.

28. Bansal, G.; Thanikachalam, P.V.; Maurya, R.K.; Chawla, P.; Ramamurthy, S. An overview on medicinal perspective of thiazolidine-2,4-dione: A remarkable scaffold in the treatment of type 2 diabetes. Journal of Advanced Research 2020, 23, 163-205, https://doi.org/10.1016/j.jare.2020.01.008.

29. Mor, S.; Sindhu, S. Synthesis, Type II diabetes inhibitory activity, antimicrobial evaluation and docking studies of indeno[1,2-c]pyrazol-4(1H)-ones. Med. Chem. Res. 2020, 29, 46-62, https://doi.org/10.1007/s00044-019-02457-8.

30. Sethi, N. S.; Prasad, D. N.; Singh, R. K. An Insight into the Synthesis and SAR of 2,4-Thiazolidinediones (2,4-TZD) as Multifunctional Scaffold: A Review. Rev. Med. Chem. 2020, 20, 308-330, https://doi.org/10.2174/1389557519666191029102838.

31. Shahzad, D.; Saeed, A.; Larik, F.A.; Channar, P.A.; Abbas, Q.; Alajmi, M.F.; Arshad, M.I.; Erben, M.F.; Hassan, M.; Raza, H.; Seo, S.-Y.; El-Seedi, H.R. Novel C-2 Symmetric Molecules as $\alpha$-Glucosidase and $\alpha$ Amylase Inhibitors: Design, Synthesis, Kinetic Evaluation, Molecular Docking and Pharmacokinetics. Molecules 2019, 24, https://doi.org/10.3390/molecules24081511. 
32. Armarego, W.L.F. Purification of laboratory chemicals; Butterworth-Heinemann: 2017 , https://doi.org/10.1016/C2009-0-64000-9.

33. Matiichuk, V.S.; Potopnyk, M.A.; Obushak, N.D. Molecular design of pyrazolo[3,4-d]pyridazines. Russ. J. Org. Chem. 2008, 44, 1352-1361, https://doi.org/10.1134/S1070428008090182.

34. Bratenko, M.K.; Barus, M.M.; Vovk, M.V. Polyfunctional pyrazoles 5*. preparative synthesis of 1-aryl-4formylpyrazole- 3-carboxylic acids. Chemistry of Heterocyclic Compounds 2009, 45, 1464-1468, https://doi.org/10.1007/s10593-010-0451-z. 